\title{
PENDIDIKAN HOLISTIK JIDDU KRISHNAMURTI
}

\author{
Oleh : \\ Krisna Sukma Yogiswari \\ Email: yogiswarikrisna@gmail.com
}

\begin{abstract}
Abstrak
Pendidikan merupakan cara yang strategis kaitannya dengan upaya individu mengembangkan potensinya. Strategi pembelajaran terus diperbaiki guna tercapainya cita-cita pendidikan itu sendiri. Pendidikan holistik yang menjadi fokus kajian para aktivis dan pemerhati pendidikan. Model pendidikan holistik menekankan pentingnya perilaku psikomotorik serta keaktifan yang menyeluruh. Pengembangan kemampuan kognitif yang menyangkut nilai-nilai akademis tetap dianggap penting meskipun bukan merupakan satu-satunya tujuan utama yang harus diasah. Filsafat Jiddu Krishnamurti yang mengajarkan humanisme juga menjadi pendukung dari pendidikan holistik.
\end{abstract}

\section{Kata Kunci: Pendidikan Holistik, Humanisme}

\begin{abstract}
Education is a strategic way in relation to individual efforts to develop their potential. Learning strategies continue to be improved in order to achieve the goals of education itself. Holistic education is the focus of the study of activists and observers of education. The holistic education model emphasizes the importance of psychomotor behavior and overall activity. The development of cognitive abilities related to academic values is still considered important although it is not the sole main objective to be sharpened. The philosophy of Jiddu Krishnamurti that teaches humanism is also a supporter of holistic education.
\end{abstract}

\section{PENDAHULUAN}

Pendidikan merupakan suatu kata yang memiliki banyak definisi dan merupakan suatu hal yang tidak pernah habis untuk diperbincangkan. Hal tersebut berkaitan dengan kenyataan bahwa pendidikan merupakan kebutuhan dasar umat manusia dan merupakan titik awal bagi perkembangan peradaban. Manusia diarahkan untuk mampu mengatasi persoalan yang berubah dari masa ke masa. Kritik mengenai pendidikan akan selalu ada. Pendidikan merupakan investasi yang strategis untuk mengembangkan sumber daya manusia yang berkualitas. Diperlukan suatu sistem yang kokoh dan benar untuk mendukung proses tersebut, kaitannya dengan tujuan pendidikan yang merupakan usaha untuk memanusiakan manusia.

Sudarminta (1990:08-12), menyatakan bahwa pendidikan dimengerti secara luas dan umum sebagai usaha sadar yang dilakukan oleh pendidik melalui bimbingan, pengajaran dan latihan untuk membantu peserta didik mengalami proses pemanusiaan diri ke arah tercapainya pribadi yang dewasa susila. Kata pendidikan mengandung sekurang-kurangnya em- 
pat pengertian, yaitu bentuk kegiatan, proses buah atau produk yang dihasilkan proses tersebut, serta sebagai ilmu. Pengertian yang diberikan oleh Sudarminta tersebut menjelaskan bahwa lembaga pendidikan diharapkan dapat mengantarkan cita-cita atau kemauan manusia atau subjek didiknya, bukan sebaliknya, subjek didik yang ditekan agar mengantarkan citacita suatu lembaga pendidikan. Melihat kenyataan yang terjadi pada lembaga pendidikan saat ini, justru peserta didik dibentuk oleh suatu lembaga pendidikan agar siap bertanding dengan lembaga pendidikan lain. Hal tersebut tentu jauh dari konsep pendidikan menurut Sudarminta, yakni suatu proses pemanusiaan diri.

Manusia dalam hal ini subjek didik, bukan merupakan robot yang dapat dibentuk menjadi apapun yang orang lain kehendaki. Subjek didik tidak merdeka atau memiliki kebebasan untuk menentukan apa yang menjadi minat dan bakatnya. Pendidikan sesungguhnya memiliki tujuan untuk membebaskan manusia agar tidak mengalami penindasan dalam bentuk apapun. Driyarkara (1980:87), mengatakan bahwa pendidikan pada hakikatnya adalah suatu perbuatan fundamental dalam bentuk komunikasi antarpribadi, dan dalam komunikasi tersebut terjadi proses pemanusiaan manusia, dalam arti proses hominisasi (proses menjadikan seseorang sebagai manusia) dan humanisasi (proses pengembangan kemanusaan manusia). Pendidikan harus membantu seseorang agar tahu dan mau bertindak sebagai manusia dan bukan hanya secara instingtif saja. Jadi pendidikan adalah proses hominisasi.

Peran seorang pendidik dalam proses pendidikan amatlah menentukan, pendidik merupakan salah satu pelaku pendidikan yang paling utama.
Bagaimana suatu proses transformasi pengetahuan akan berjalan salah satunya tergantung dari peran pendidik. Pendidik memang memiliki otoritas tertentu, namun hendaknya pendidik mengesampingkan otoritasnya untuk menjadikan subjek didiknya semata-mata sebagai subjek didik yang pandai. Misi utama seorang pendidik adalah menyampaikan ilmunya dengan baik sehingga peserta didik dapat memahami apa yang ia sampaikan, serta mengantarkan subjek didik pada cita-citanya. Kenyataan yang sering dihadapi pada masa ini adalah adanya pendidik maupun lembaga pendidikan yang terlalu prosedural, sehinggga subjek didik juga dibebani oleh bermacam-macam kerumitan prosedur. Seseorang yang dididik hanya berdasarkan prosedur yang sudah ada di lembaga saja, tanpa melihat kebutuhan masing-masing individu hatinya akan tumpul karena tidak terbiasa diasah. Komputer, robot merupakan contoh benda-benda yang dapat melakukan segalanya sesuai prosedur, bahkan harus sesuai prosedur, karena memang diciptakan untuk itu. Lain halnya dengan manusia, manusia memiliki apa yang disebut sebagai hati nurani.

Para pendidik seharusnya menguasai landasan filosofis pendidikan. Landasan filosofis pendidikan harus dikuasai karena pendidikan bersifat normatif, maka dalam rangka pendidikan diperlukan asumsi yang bersifat normatif pula. Asumsi-asumsi pendidikan yang bersifat normatif itu antara lain dapat bersumber dari filsafat. Landasan filosofis pendidikan yang bersifat preskriptif dan normatif akan memberikan petunjuk tentang apa yang dicita-citakan dalam pendidikan. Alasan penting lain yaitu bahwa pendidikan tidak cukup dipahami hanya melalui pendekatan ilmiah yang bersifat par- 
sial dan deskriptif saja, melainkan perlu dipandang pula secara holistik. Adapun kajian pendidikan secara holistik dapat diwujudkan melalui pendekatan filosofis.

Konsep pendidikan yang holistik dan humanis serta memanusiakan manusia memang tidak mudah begitu saja dilaksanakan. Hal tersebut mengingat pelaku dalam sebuah pendidikan itu sendiri masih terpaku pada sistem pendidikan tertentu, namun bukan berarti tidak mungkin. Banyak tokoh dan pemerhati pendidikan mendukung konsep pendidikan holistik sebagai usaha mencapai tujuan membangun dimensi manusia yang utuh. Terdapat beberapa tokoh klasik perintis konsep holistik diantaranya adalah Carl Jung, Ralph Waldo Emerson dan Johan Pestalozzi. Tercatat pula beberapa tokoh yang dianggap sebagai pendukung pendidikan holistik. Salah satu tokoh pendukung konsep pendidikan holistik adalah Jiddu Krishnamurti.

Diskursus mengenai pendidikan tidak akan pernah selesai untuk dikaji dan selalu menjadi hal yang menarik. Jiddu krishnamurti merupakan seorang pemikir dan pembicara yang unik. Jiddu Krishnamurti tidak pernah menulis secara langsung pemikiran-pemikirannya dalam sebuah buku, sehingga pemikiran dan sosoknya dianggap kurang familiar kecuali oleh para peneliti subjeksubjek spiritual. Pemikirannya mengenai pendidikan belum banyak yang mengkaji dan meneliti secara serius, padahal sangat relevan untuk perbaikan sistem pendidikan yang selalu menjadi sorotan dari waktu ke waktu. Persoalan mengenai pendidikan selalu menjadi kegelisahan penulis berdasarkan kenyataan-kenyataan di sekitar dan pengalamanpengalaman yang penulis alami secara langsung. Alasan-alasan tersebut men- jadi dasar bagi penelitian yang terkait dengan pemikiran Jiddu Krishnamurti mengenai pendidikan.

\section{PEMBAHASAN}

\section{Konsep Pendidikan Holistik}

Istilah holistik merupakan sebuah persitilahan yang berasal dari bahasa Inggris dari akar kata "whole" yang berarti keseluruhan (Webster, 1980: 643). Dengan pengambilan makna dasar seperti ini, menurut Husein Heriyanto (2003: 12) paradigma holistik dapat diartikan sebagai suatu cara pandang yang menyeluruh dalam mempersepsi realitas. Berpandangan holistik artinya lebih memandang aspek keseluruhan daripada bagianbagian, bercorak sistemik, terintegrasi, kompleks, dinamis, nonmekanik, dan non-linier.

Di samping itu, istilah holistik juga diambil dari kata dasar heal (penyembuhan) dan health (kesehatan). Secara etimologis memiliki akar kata yang sama dengan istilah whole (keseluruhan) (Webster, 1980: 644). Hal ini mengindikasikan bahwa berpikir holistik berarti berpikir sehat. Dalam ranah pendidikan, pendidikan holistik merupakan suatu metode pendidikan yang membangun manusia secara keseluruhan dan utuh dengan mengembangkan semua potensi manusia yang mencakup potensi sosial-emosi, potensi intelektual, potensi moral atau karakter, kreatifitas, dan spiritual. Tujuan pendidikan holistik adalah untuk membentuk manusia holistik. Manusia holistik adalah manusia yang mampu mengembangkan seluruh potensi yang ada dalam dirinya. Potensi yang ada dalam diri manusia meliputi potensi akademik, potensi fisik, potensi sosial, potensi kreatif, potensi emosi dan potensi spiritual (Megawangi, 2005: 6 
$-7)$.

\section{Manusia}

mengembangkan

yang

seluruh
Jeremy Henzell-Thomas merupakan mampu suatu upaya membangun secara utuh poten- dan seimbang pada setiap murid dalam sinya merupakan manusia yang holis- seluruh aspek pembelajaran, yang tik, yaitu manusia pembelajar sejati mencakup spiritual, moral, imajinatif, yang selalu menyadari bahwa intelektual, budaya, estetika, emosi dan dirinya adalah bagian dari sebuah fisik yang mengarahkan seluruh aspeksistem kehidupan yang luas, sehingga aspek tersebut ke arah pencapaian selalu ingin memberikan kontribusi sebuah kesadaran tentang hubpositif kepada lingkungan hidupnya. ungannya dengan Tuhan yang meruTujuan pendidikan di Indonesia pakan tujuan akhir dari semua keyang tertuang pada Undang-Undang hidupan di dunia.

Republik Indonesia nomor 20 tahun

Pendidikan seyogyanya menjadi 2003 adalah untuk membentuk manusia wahana strategis bagi upaya mengemyang holistik dan berkarakter bangkan segenap potensi individu, se(Megawangi, 2005: 8). Manusia holis- hingga cita-cita membangun manusia tik dan berkarakter merupakan social Indonesia seutuhnya dapat tercapai capital bagi perkembangan suatu (Latifah, 2008: 43).

bangsa.

Pendidikan holistik membantu

Dalam pelaksanaannya, pen- mengembangkan potensi individu dadidikan holistik berpijak pada tiga lam suasana pembelajaran yang lebih prinsip, yaitu:

menyenangkan dan menggairahkan,

a. Connectedness adalah konsep demokratis dan humanis melalui peninterkoneksi yang berasal dari galaman dalam berinteraksi dengan filosofi holisme yang kemudian lingkungannya. Melalui pendidikan berkembang menjadi konsep holistik, peserta didik diharapkan ekologi, fisika kuantum dan teori dapat menjadi dirinya sendiri. Dalam sistem.

arti, para siswa dapat memperoleh

b. Wholeness (keseluruhan) bukan kebebasan psikologis, mengambil sekedar penjumlahan dari setiap ba- keputusan yang baik, belajar melalui giannya. Sistem wholeness bersifat cara yang sesuai dengan dirinya, dinamis sehingga tidak bisa memperoleh kecakapan sosial, serta dideduksi hanya dengan mempela- dapat mengembangkan karakter dan jari setiap komponennya. emosionalnya. Oleh karena itu,

c. Being (menjadi) adalah tentang me- upaya pendidikan holistik tidak lain rasakan sepenuhnya kekinian. Hal adalah untuk membangun secara utuh ini berkaitan dengan kedalaman ji- dan seimbang pada setiap murid dalam wa, kebijaksanaan (wisdom), wawa- seluruh aspek pembelajaran, yang mensan (insight), kejujuran, dan ke- cakup spiritual, moral, imajinatif, intelotentikan (Latifah, 2008: 7-9).

Berdasarkan pengertian para- yang mengarahkan seluruh aspek-aspek digma sebelumnya dan pengertian ho- tersebut ke arah pencapaian sebuah listik di atas dapat disimpulkan bahwa kesadaran tentang hubungannya dengan paradigma pendidikan holistik adalah Tuhan yang merupakan tujuan akhir cara memandang pendidikan yang me- dari semua kehidupan di dunia nyeluruh bukan merupakan bagian- (Megawangi, 2005: 34)

bagian yang parsial, terbatas, dan Pada saat ini banyak model kaku. Pendidikan holistik menurut pendidikan yang berdasarkan pan-

Pendidikan Holistik Jiddu Krishnamurti 
dangan abad XIX yang menekankan pada (belajar terkotak-kotak), linier thinking (bukan sistem) dan (fisik yang utama), yang membuat siswa sulit untuk memahami relevance dan value antara yang dipelajari disekolah dengan kehidupannya. Oleh karena itu, dibutuhkan sistem pendidikan yang terpusat pada anak yang dibangun berdasarkan asumsi connectedness, wholeness, dan being fully human.

Untuk mencapai tujuan pendidikan holistik, maka kurikulum yang dirancang harus diarahkan untuk mencapai tujuan pembentukan manusia holistik. Termasuk di dalamnya membentuk anak menjadi pembelajar sejati, yang senantiasa berpikir holistik, bahwa segala sesuatu adalah saling terkait atau berhubungan. Beberapa pendekatan pembelajaran yang dianggap efektif untuk menjadikan manusia pembelajar sejati di antaranya adalah pendekatan siswa belajar aktif, pendekatan yang merangsang daya minat anak atau rasa keingintahuan anak, pendekatan belajar bersama dalam kelompok, kurikulum terintegrasi, dan lain-lain (Megawangi, 2005: 41).

Pendidikan holistik dapat diaplikasikan dalam proses pembelajaran dengan beberapa cara, di antaranya dengan menerapkan Integrated Learning atau pembelajaran terintergrasi/terpadu, yaitu suatu pembelajaran yang memadukan berbagai materi dalam satu sajian pembelajaran. Inti pembelajaran ini adalah agar siswa memahami keterkaitan antara satu materi dengan materi lainnya, antara saru mata pelajaran dengan mata pelajaran lain. Dari integrated learning inilah muncul istilah integrated curriculum (kurikulum terintegrasi/terpadu).

Melalui pendidikan holistik, peserta didik diharapkan dapat menjadi dirinya sendiri (learning to be), dalam arti dapat memperoleh kebebasan psikologis, mengambil keputusan yang baik, belajar melalui cara yang sesuai dengan dirinya, memperoleh kecakapan sosial, serta dapat mengembangkan karakter dan emosionalnya. Jika merujuk pada pemikiran Abraham Maslow dalam tulisan Syaifuddin Sabda (tt: 56-57), maka pendidikan harus dapat mengantarkan peserta didik untuk memperoleh aktualisasi diri (selfactualization) yang ditandai dengan adanya kesadaran, kejujuran, kebebasan atau kemandirian, dan kepercayaan. Dalam konteks ini, Howard Gardner menyebutkan ada sembilan kecerdasan bagi siswa yang harus dikembangkan dan mendapat perhatian khusus, yaitu:

a. Kecerdasan linguistik kecerdasan untuk membaca, menulis, bercerita, bermain kata dan menjelaskan. Pembentukan ini agar anak kelak berkemampuan dalam bidang pemberitaan, jurnalistik, berpidato, debat, percakapan dan lain-lain.

b. Kecerdasan logis atau matematis yaitu kecerdasan dalam bereksperimen, bertanya, memecahkan teka-teki dan berhitung. Pembentukan ini diarahkan agar anak berhasil dalam bidang matematika, akutansi, program komputer, perbankan dan lain-lain.

c. Kecerdasan spatial atau visual yaitu kecerdasan dalam mendisain, menggambar, membuat sketsa, menvisualisasikan. Pembentukan kecerdasan ini agar anak memiliki kemampuan yang baik antara lain membuat peta, fotografi, melukis, desain rencang bangun dan lainlain.

d. Kecerdasan body atau kenestetik yaitu kecerdasan untuk menari, berlari, membangun, menyentuh, 
bergerak dan kegiatan fisik lainnya. Pembinaan kecerdasan ini agar anak cemerlang dalam olah raga, seni tari, seni pahat, dan sebagainya.

e. Kecerdasan musikal adalah kecerdasan untuk menyanyi, bersiul, bersenandung, menghentak-hentakkan kaki atau tangan, mendengar bunyibunyian. Pembinaan kecerdasan ini diarahkan agar anak mempunyai kecenderungan ini akan sukses dalam bernyanyi, menggubah lagu, memainkan alat musik dan lainlain.

f. Kecerdasan interpersonal yaitu kecerdasan untuk memimpin, mengatur, menghubungkan, bekerja sama, berpesta dll. Pembinaan kecerdasan ini agar anak berhasil dalam pekerjaan seperti guru, pekerja sosial, pemimpin kelompok, organisasi, politik.

g. Kecerdasan intrapersonal yaitu kecerdasan untuk suka mengkhayal, berdiam diri, merencanakan, menetapkan tujuan, refleksi. Pembinaan kecerdasan ini agar anak cemerlang dalam filsafat, menulis penelitian dan sebagainya.

h. Kecerdasan natural yaitu kecerdasan untuk suka berjalan, berkemah, berhubungan dengan alam terbuka, tumbuh-tumbuhan, hewan. Pembinaan kecerdasan ini agar anak dapat menguasai dan menyenangi dengan baik bidang botani, lingkungan hidup, kedokteran dan lain- lain.

i. Kecerdasan eksistensialis yaitu kecerdasan untuk suka berfilsafat, suka agama, kebudayaan dan isuisu sosial. Pada umumnya mereka berhasil dalam bidang keagamaan dan psikologi (Sulhan, 2006: 1721).

\section{Pemikiran Jiddu Krishnamurti}

Pemikiran Jiddu Krishnamurti menurut Andrilolo adalah upaya yang revolusioner yang mengarah pada kebebasan mutlak manusia dari apapun. Pemikiran yang digagas Krishnamurti juga dapat dilihat dalam pandangan Nietzche, Husserl, Descartes dan Bergson, walaupun dalam beberapa hal ada yang berbeda bahkan bertolak belakang. Kajian terhadap Jiddu Krishnamurti merupakan persoalan yang signifikan bagi perkembangan keilmuan dan bahkan perkembangan manusia secara khususnya (Andrilolo, 2010: 142).

Andrilolo menyimpulkan bahwa Jiddu Krishnamurti merupakan seorang eksistensialis. Jiddu Krishnamurti menempatkan manusia sebagai ,aku" yang selalu hadir dalam "akuaku" yang lain. Posisi "aku" sebagai penentu kehidupannya, seperti karakteristik yang dimiliki oleh eksistensialisme. Begitu pula tentang keberanian manusia dalam berdiri sendiri mengartikan semua yang dilihatnya. Dalam proses pencapaian pengetahuanatau epistemologinya, Krishnamurti memiliki kesamaan dengan fenomenologi yang menekankan pengetahuan langsung menggunakan intusi (Andrilolo, 2010: 144).

Setiawan (2015: 40-41), pemikiran tentang konsep manusia menurut Jiddu Krishnamurti senada dengan konsep pemikiran Shunryu Suzuki, manusia memiliki dua eksistensi, yang pertama dapat dilihat dan yang kedua tidak dapat dilihat. Antara yang pertama dan yang kedua tersebut selalu tarik menarik dan sifatnya imperative, karena terdapat unsur kehendak dan unsur keinginan.

Jalan pemikiran Jiddu Krishnamurti menurut Oto Suastika (1981: 05) sejajar dengan jalan pemikiran $\mathrm{Ki}$ Ageng Suryomentaram, seorang spiritualis Jawa, walaupun kedua 
tokoh tersebut tidak saling terkait dan tidak saling mempengaruhi karena perbedaan waktu, tempat dan juga bahasa. Jiddu Krishnamurti mendasarkan ajarannya pada Self Knowledge begitu pula Ki Ageng Suryomentaram mendasarkan ajarannya pada pangawikan pribadi (pengertian tentang diri sendiri).

Jiddu Krishnamurti, laki-laki kelahiran India (1895-1986) ini mengaku tidak menjadi warga negara manapun. Karl Marx dan Jiddu Krishnamurti sama-sama mempunyai pemikiran tentang suatu perubahan. Jika Marx menitikberatkan pada perubahan sistem, maka Jiddu Krishnamurti menitikberatkan pada perubahan batin manusia. Bagi Jiddu Krishnamurti, hanya melalui perubahan batin radikal dan menyeluruh pada individu dapat terjadi perubahan pada sosial masyarakat, karena masyarakat adalah perpanjangan individu. Seperti apa wujud individu, demikian pula wujud masyarakat (Basuki, 2008:306).

Basuki (2009: 01) mengatakan bahwa tidak seperti Ivan Illich maupun Paulo Freire yang menekankan perubahan pada sistem dan dominasi pemerintah, jiddu Krishnamurti menekankan perubahan pada pikiran individu, atau yang sering disebutnya sebagai revolusi batin. Perubahan bukan hanya mengenai adanya transfer pengetahuan semata, akan tetapi juga sebuah proses pemahaman terhadap diri sendiri. Guru dan siswa harus merasa bebas, bahagia, penuh cinta kasih, penuh perhatian dimana scientific mind dan religious mind dapat dipisahkan dan disadari secara simultan. Menurut Ari Basuki, Jiddu Krishnamurti percaya bahwa revolusi batin adalah yang paling penting diaktualisasikan dalam masyarakat.

Jiddu Krishnamurti yakin bahwa perubahan radikal melalui revolusi batin dapat terjadi dalam setiap individu, bukan secara bertahap melainkan seketika. Jiddu Krishnamurti membantu diri sendiri untuk melihat dalam keadaan yang sebenarnya, karena dalam penglihatan yang benar-benar jelas itulah revolusi batin timbul (Lutyens, 1982:05). Orang-orang yang relijius menurut Jiddu Krishnamurti,bukanlah orang-orang yang memuja dewa, sebuah patung yang dibuat oleh tangan atau oleh akal budi, tetapi orang-orang yang benarbenar menyelidiki apa kebenaran itu, apa Tuhan itu, dan orang yang seperti itu benar-benar terdidik. Jiddu Krishnamurti mengatakan, orang -orang itu mungkin tidak bersekolah, ia mungkin tidak mempunyai bukubuku, ia bahkan mungkin tidak dapat membaca, tetapi ia telah membebaskan dirinya dari rasa takut, dari egoisme, dari mementingkan diri sendiri serta dari ambisi. Fungsi pendidikan pertama-tama ialah membantu manusia untuk membebaskan diri dari kepicikannya sendiri dan dari ambisiambisinya yang bodoh (Lutyens, 1982:231-232).

Jiddu Krishnamurti dalam pandangannya menolak semua metode untuk mendapatkan sesuatu. Jiddu Krishnamurti mengatakan bahwa tidak ada jalan menuju Tuhan dan dalam hal kebebasan menurutnya tidak ada suatu teori atau metode yang dapat mengantarkan manusia ke dalam kebebasan. Tidak ada jalan menuju kebebasan karena kebebasan bukan merupakan suatu tujuan. Jiddu Krishnamurti menginngkari semua metode, sehingga menurutnya kebebasan itu hanya dapat ditemukan oleh dirinya sendiri di dalam dirinya sendiri (Osho, 1992:61). 
Pendidikan Holistik Perspektif Jiddu Krishnamurti

Pendidikan holistik bukan merupakan strategi "kemarin sore" dalam dunia pendidikan nasional maupun internasional. Pendidikan holistik telah lama diterapkan di negara-negara maju seperti Jerman, Kanada, Perancis, Singapura, Jepang, Korea dan Australia. Semua negara pada dasarnya menjunjung tinggi pendidikan sebagai sarana mencerdaskan bangsa serta untuk mengatasi berbagai macam kemerosotan dalam hal materiilspirituil. Strategi holistik dianggap sebagai strategi pendidikan yang utuh menyeluruh. Tujuan pendidikan holistik tidak hanya dalam aspek pencerdasaan intelektual saja, namun juga emosional, spiritual dan sosial, sehingga dianggap mampu mengatasi berbagai permasalahan suatu bangsa dan negara (Rubiyanto, 2010:05-06).

Menurut J Krishnamurti, Pendidikan manusia hari ini adalah suatu pendidikan yang hanya mampu mengajarkan, bagaimana menghapal tanggal dalam satu proses sejarah, bagaimana memecahkan soal matematika, bagaimana agar bisa menghasilkan para pekerja yang murah, dan bagaimana hidup seolah begitu adanya. Ini adalah kesalahan yang sejak ratusan bahkan ribuan tahun dipelihara. Disamping itu pendidikan akhirnya hanya proses pengajaran akan hal-hal di luar diri, bukan pengajaran agung tentang diri.

Pendidikan seperti apa yang harus diciptakan? Menurut Krishnamurti, Tidak ada yang mesti diciptakan lagi, selain bagaimana orang bisa sadar akan kengerian-kengerian yang terjadi dan berusaha merubahnya. Tidak mesti diciptakan lagi karena pendidikan hari ini sudah maju dalam bidang metode, tetapi tertinggal dalam bagaimana memanusiakan manusia. Mengajarkan kesadaran kemanusiaan-etis, spiritual—mungkin seolah terdengar konyol, tapi ini yang dibutuhkan manusia hari ini. Walaupun itu susah, seseorang harus terus melakukannya. Menjadi sadar akan lingkungan sekitar yang penuh dengan kengerian, kekejaman, kejahatan dan lainnya. Proses ini berawal dari diri sendiri yang menyadari secara penuh kegiatan diri sendiri, memantau cara kerja pikiran dengan cara meditasi, dan terus menumbuhkan kepekaan terhadap lingkungan di luar diri (Krishnamurti, 1997: 31).

Tujuan pendidikan menurut konsep yang utuh ini adalah untuk membangun manusia seutuhnya. Hal ini seperti yang juga termaktub dalam tujuan pendidikan nasional kita. Seluruh aspek yang dimiliki anak melalui pandangan holistik ini (The whole child education) akan berkembang dengan patut termasuk kesadaran bahwa anak adalah bagian dari anggota keluarganya, sekolah, lingkungan, masyarakat, dan komunitas global.

Krishnamurti mengatakan bahwa kegagalan sistem pendidikan untuk menjadikan manusia berwawasan holistik disebabkan pendidikan modern lebih bertumpu pada dunia sekuler, terlepas dari makna spiritual. Bagi Krishnamurti kesatuan integral adalah sakral dan segala sesuatu adalah bagian dari kesatuan integral. Oleh sebab itu segala sesuatu mesti memiliki makna yang sakral. Manusia perlu diberikan perangkat untuk mencapai pemahaman makna spiritual. Masalahnya sistem pendidikan modern sangat terspesialisasi dan telah memecahbelah keseluruhan menjadi bagian-bagian yang terpisah yang tidak lagi saling bermakna. Dalam kegiatan pendidikan konvensional seluruh potensi manusia yang dilibatkan hanya sebatas pada kognitif dan pisik semata, tanpa meli- 
batkan aspek emosi dan spiritual.

Hakikat dari pendidikan menurut Krishnamurti ini dikemas Scott Forbes dalam tujuan pendidikan untuk mendidikan seluruh aspek yang dimiliki manusia (All part of the person), mendidikan manusia sebagai kesatuan yang utuh (The person as the whole), mendidikan manusia sebagai bagian dari keseluruhan (The person within the whole), yaitu sebagai bagian dari masyarakat, komunitas manusia, dan alam semesta.

Seseorang seharusnya tidak menjadi latah ketika sesuatu diterima oleh orang lain. Memang butuh keberanian untuk hidup tidak seperti biasanya, tidak menyesuaikan diri dengan pola yang lama atau pola yang baru. Kita harus menemukan apa artinya tidak pernah menyesuaikan diri dan apa artinya hidup tanpa rasa-takut. Semua itu usaha untuk melawan kengerian, kejahatan, yang seolah biasa, agar kita tidak terjebak kedalam satu situasi di mana kita menjadi bebal dalam kengerian, dan menikmati kengerian itu. Pada dasarnya setiap detik, menit, hari manusia adalah mahluk yang terus belajar-karena dengan itu kita bisa merasakan ada semacam rangsangan untuk menaruh perhatian kepada sesuatu, bukan konsentrasi. Jika seseorang menaruh perhatian, manusia tersebut melihat segala sesuatu jauh lebih jelas. Bisa mendengar nyanyian burung jauh lebih nyata. Kita mampu membedakan berbagai suara. Jika kita menaruh perhatian, kita melihat dengan luar biasa jelasnya. Perhatian berbeda dengan konsentrasi. Jika seseorang berkonsentrasi, kita tidak melihat semuanya. Tetapi jika kita menaruh perhatian, kita melihat banyak hal (Krishnamurti, 1979: 7).

Perhatian akan diri dan sekitar dalam hal ini, yang menjadi metode untuk memecahkan semua kengerian, kejahatan, dan kebebalan tersebut. Kita harus lebih mendasarkan pendidikan hari ini untuk memecahkan krisis kemanusiaan, krisis ekologis, dan krisis spiritualitas. Perhatian akan semuanya ini, dengan mengedepankan pendidikan yang tidak terkotak-kotak, tetapi suatu pendidikan holistik. Jika pendidikan adalah suatu usaha untuk menjadikan manusia mempunyai kesadaran spiritualis-kritis, sehingga ia bisa memahami lingkungan sekitarnya dengan baik, maka sudah selayaknya setiap orang menjadikan dirinya sebagai mahluk yang mempunyai kepekaan agar tidak melakukan kengerian tersebut. Memilih berbeda dengan masarakat secara umum akhirnya menjadi pilihan terakhir untuk menciptakan suatu keadaan di mana melihat keadaan tidak baikkejahatan, kelaparan, pencurian, kengerian-jelas sesuatu yang harus diperbaiki (Kejahatan, 2011: 9)

Pendidikan akan berjalan dengan baik apabila krangkeng pengalaman dilepaskan. Ini jadi penting, sebab manusia akan selalu menemukan sesuatu yang baru jika dia meninggalkan yang lama, atau meninggalkan sesuatu yang telah usang. Maka dalam pendidikan yang benar, sudah semestinya kita "meninggalkan" pengetahuan yang sudah ada, karena, menurut Krihsnamurti, pengetahuan adalah produk masalalu. Agar kita mendapatkan sesuatu yang baru, maka pengetahuan jangan menjadi sesuatu yang berkuasa untuk menilai hari ini. Ketika itu sudah bisa dilaksanakan, maka setiap orang akan menjadi orang yang berpendidikan karena dia mendapatkan sesuatu yang baru, bukan tafsirantafsiran atas hari ini oleh pengetahuan masalalu. Intelegensi akan timbul jika 
menggunakan pengetahuan. Tapi intelegensi jelas berbeda dengan pengetahuan. Intelegensi yaitu kemampuan berpikir secara jernih, objektif, waras dan sehat. Intelegensi adalah keadaan yang di dalamnya tidak terlibat emosi pribadi, pendapat, prasangka, atau kecenderungan pribadi. Intelegensi adalah kemampuan memahami secara langsung, sikap batin yang waspada. Dari itu intelegensi mempunya peran penting dalam belajar. Intelegensi hadir pada saat senggang. Senggang berarti batin yang tidak terus sibuk dengan sesuatu, sibuk dengan masalah, dengan kesenangan ini atau itu; dengan kenikmatan fisik tertentu. Arti senggang ialah, bahwa batin mempunyai waktu tak terbatas untuk mengamati: mengamati apa yang terjadi di sekelilingnya dan apa yang berlangsung dalam dirinya sendiri. Senggang berarti ada kebebasan, dan hanya dalam keadaan inilah batin mungkin belajar tidak hanya sains, matematik, sejarah, tetapi juga tentang dirinya sendiri (Krisnamurti, 1983: 7). Pendidikan dan intelegensia jelas erat berkaitan, karena dalam proses belajar yang sesungguhnya, yang terjadi adalah bagaimana setiap orang belajar mengamati, bebas dari masa lalu. Intelegensi membantu setiap orang bebas dari masa lalu karena ia selalu baru, tidak terkuasai oleh pengetahuan yang bersifat terspesialisasi (krishnamurti, 1983: 8).

\section{PENUTUP}

Menganalisis pemikiran Jiddu Krishnamurti tentang pendidikan, maka dapat ditarik kesimpulan tentang; konsep pendidikan holistik merupakan konsep pendidikan yang mengupayakan keseimbangan dalam mengoptimalkan potensi subjek didik dalam berbagai aspek. Semua aspek, yaitu emosional, intelektual, artistik dan spiritual dipandang sebagai sesuatu yang penting. Tujuan pendidikan holistik adalah membangun seluruh dimensi yang terdapat pada manusia, dalam hal ini subjek didik sehingga menjadikan manusia yang cerdas secara emosional, spiritual maupun intelektual.

Konsep pendidikan Jiddu Krishnamurti merupakan pendidikan yang dimulai dengan dasar pengenalan dan pemahaman terhadap diri sendiri. Proses memahami tersebut hanya akan terjadi jika manusia mampu mengenali dirinya sendiri dan terbebas dari rasa takut dan terbelenggu. Proses tersebut merupakan proses yang menyeluruh secara psikologis. Demikianlah, pendidikan merupakan proses pemahaman diri, kemudian berlanjut pada pemahaman terhadap sesama manusia, dan keseluruhan eksistensi. Tujuan pendidikan yaitu untuk membangun hubungan yang baik antarmanusia dan lingkungan masyarakat. Pemikiran Jiddu Krishnamurti adalah bahwa rohani dan batin manusia merupakan kunci kesadaran terhadap realitas. Manusia mengetahui sesuatu melalui kesadaran jiwa. Manusia mengetahui adanya realitas melalui jasmani. Manusia merupakan bagian dari alam dan tunduk pada hukum-hukum alam. Perbedaan mendasar terletak pada metode dalam proses pembelajaran. Jiddu Krishnamurti menentang konsep keteladanan sementara dalam filsafat pendidikan esensialisme, pendidik diharapkan merupakan seseorang yang memiliki kapabilitas sehingga dapat dijadikan teladan.

\section{DAFTAR PUSTAKA}

Andrilolo. 2010. Konsep Manusia dalam Pandangan Jiddu Krishnamurti (1895-1986). Yogyakarta: tidak diterbitkan. 